\title{
Human Cytomegalovirus (HCMV) infection was not correlated with overall survival in glioblastomas
}

\author{
S. HAN ${ }^{1}$, P. F. WANG 2 , Y. X. XING ${ }^{2}$, H. W. SONG ${ }^{2}, \mathrm{~K} \mathrm{YAO}^{3}$, Z. X. $\mathrm{LIN}^{1, \star}$ \\ ${ }^{1}$ Department of Neurosurgery, The First Affiliated Hospital of Fujian Medical University, Fuzhou, Fujian, China; ${ }^{2}$ Department of Neurosurgery, \\ Sanbo Brain Hospital, Capital Medical University, Beijing, China; ${ }^{3}$ Department of Pathology, Sanbo Brain Hospital, Capital Medical University, \\ Beijing, China
}

${ }^{*}$ Correspondence: Lzx1967@sina.com

Received January 24, 2017 / Accepted May 29, 2017

\begin{abstract}
There are many arguments about the presence of HCMV (Human Cytomegalovirus) in malignant gliomas. This study was to investigate the presence and prognostic value of HCMV in glioblastomas. 68 patients including 64 primary glioblastomas and 4 secondary glioblastomas were involved in this study. Immunofluorescence was adopted for detecting glycoprotein B (gB) and glycoprotein H (gH) of HCMV in glioblastoma tissues. Kaplan-Meier Analysis and Chi Square were used to evaluate patients' survival and the association between HCMV infection and patients' characteristics, respectively. We found that the presence rate of $\mathrm{gB}$ and $\mathrm{gH}$ in glioblastomas were $48.5 \%(33 / 68)$ and $42.6 \%(29 / 68)$, respectively. The co-occurrence of $\mathrm{gB}$ and $\mathrm{gH}$ was $30.8 \%$, and the presence rates of either $\mathrm{gB}$ or $\mathrm{gH}$ in glioblastomas were $60.3 \%$. While IDH $\mathrm{R} 132 \mathrm{H}$ mutations were significantly correlated with a better clinical outcome $(\mathrm{p}=0.006)$, the presence of neither $\mathrm{gB}(\mathrm{p}=0.551)$ nor $\mathrm{gH}(\mathrm{p}=0.871)$ had prognostic values. Furthermore, there was no significant association between the presence of HCMV and gliomas' characteristics, neither with patients' age, gender, KPS, IDH mutations nor PTEN loss. In conclusion, our results support the fact that HCMV is detected in glioblastomas. However, no predictive value of HCMV was observed, the treatment of glioblastomas targeting HCMV was needed to be reevaluated by studies again.
\end{abstract}

Key words: glioblastoma, human cytomegalovirus, immunofluorescence, molecular pathology

Glioblastomas (GBM) are the most common malignant brain tumors with a median survival around 14-16 months [1]. Identification of glioma cancer stem cells (GCSC) is of great significance in underlining the aggressive behavior of glioblastomas [2]. Recent studies suggest a strong relationship between HCMV (Human Cytomegalovirus) infection and GCSC features of GBM [3, 4]. However, in 2002 was HCMV first detected in malignant gliomas, suggesting a role of HCMV in tumor genesis [5]. During the decades, many arguments arose out of presence of HCMV in blood and tumor tissue of glioblastomas, suspecting HCMV as a pathogenesis in glioblastomas [6-15]. The characteristics of HCMV infection has been well established that HCMV infection is closely correlated with regional economy, race and environment [5, 7, 8, 13, 14, 16, 17]. Additionally, HCMV infection is mostly prevalent in astrocytic gliomas and glioblastomas $[18,19]$. The identification of IDH mutations in gliomas suggested that the genetic changes in two groups of gliomas were completely different [20]. IDH mutations were less common in glioblastoma than grade II-III gliomas. Also patients carrying IDH mutations had improved overall survivals $[21,22]$. The classification of gliomas based on WHO 2007 pathology is presented with different clinical outcomes, when IDH mutations were involved $[23,24]$. The updated WHO 2016 classification of glioblastomas included IDH mutations [25]. The gH and gB of the HCMV were two virion envelope proteins essential for the infection of host [26]. The two proteins were specific and used for the detection of HCMV [7, 27-29].

In this study, we detected the presence of HCMV with the immunofluorescence of $\mathrm{gB}$ and $\mathrm{gH}$ in glioblastomas. The relationship between HCMV presence and gliomas' characteristics was also analyzed here.

\section{Patients and methods}

Patients. There were 64 primary glioblastoma and 4 secondary glioblastoma patients involved in this study. All of them underwent a surgical treatment in Sanbo Brain Hospital from 2014 to 2015. Medical records like age, gender and Karnofsky Performance Status (KPS) scores were obtained in details. This study was approved by Ethics Committee of 
Sanbo Brain Hospital. The written informed consents were obtained from all the patients involved in this study.

Immunohistochemistry (IHC). Immunostaining of IDH1 R132H mutations and PTEN were performed as in our previous research. Tumor samples were fixed with $10 \%$ neutral buffered formalin, and further embedded in paraffin. Antigen retrieval was facilitated by heating, and endogenous peroxidases were neutralized with $3 \%$ hydrogen peroxide routinely [30]. Primary antibodies against IDH1 R132H

Table 1. Study population characteristics.

\begin{tabular}{|c|c|c|}
\hline Variable & Number & $\%$ \\
\hline \multicolumn{3}{|l|}{ Age } \\
\hline mean & $48.15 \pm 1.86$ & - \\
\hline median & 48 & - \\
\hline \multicolumn{3}{|l|}{ Gender } \\
\hline female & 33 & 48.53 \\
\hline male & 35 & 51.47 \\
\hline \multicolumn{3}{|l|}{ KPS } \\
\hline$\geq 70$ & 55 & 80.88 \\
\hline$<70$ & 13 & 19.12 \\
\hline \multicolumn{3}{|l|}{ Surgery } \\
\hline non-GTR & 21 & 30.88 \\
\hline GTR & 47 & 69.12 \\
\hline \multicolumn{3}{|l|}{ Stupp protocol } \\
\hline incomplete & 14 & 20.59 \\
\hline complete & 42 & 61.76 \\
\hline NA & 12 & 17.65 \\
\hline \multicolumn{3}{|l|}{ IDH mutation } \\
\hline mutant & 13 & 19.12 \\
\hline wild-type & 55 & 80.88 \\
\hline \multicolumn{3}{|l|}{ PTEN } \\
\hline loss & 11 & 16.18 \\
\hline presence & 57 & 83.82 \\
\hline
\end{tabular}

(Dianova 1:100) and PTEN (ZSGB-BIO 1:150) were applied overnight at $4{ }^{\circ} \mathrm{C}$. Poly-HRP Anti-Mouse/Rabbit IgG Detection System (PV-9000 ZSGB-BIO, China) was employed for $30 \mathrm{~min}$ at $37^{\circ} \mathrm{C}$. The cutoff values were $10 \%$ for IDH1 R132H, p53, MGMT and PDGFR, and 30\% for Ki67.

Immunofluorescence (IF). Immunofluorescence was performed for the detection of CMV glycoprotein $\mathrm{H}(\mathrm{gH})$ and glycoprotein $\mathrm{B}(\mathrm{gB})$ in glioma tissues. All the experimental procedures were carried out in strict accordance with the manufacturer's instructions. Briefly, tumors were quickly frozen in liquid nitrogen and stored at $-80^{\circ} \mathrm{C}$. Then, the tumor samples were cut into $7 \mu \mathrm{m}$ thick sections, and the sections were thawed at room temperature prior to fixing in cold acetone for 10 minutes. A mouse monoclonal antibody against either CMV gH (sc-58113) or CMV gB (sc-70943) was purchased from SANTA CRUZ. Fluorescence microscope (BX-51 OLYMPUS JAPAN) was employed for the capture of the image.

Statistics. Student's t test, Chi Square and Kaplan-Meier Analysis were employed for data analysis, with the use of SPSS 22.0.

\section{Results}

Study characteristics. 68 patients were involved in this study, including 33 females and 35 males respectively. The follow-up was available in 59 cases. All the patients underwent an operation, and 42 of them postoperatively had a complete radiochemotherapy according to the Stupp's protocol [31] (Table 1).

Detection of HCMV. Immunofluorescence was used to detect the presence of HCMV in glioblastoma tissues. Representative images are shown in Figure 1. The $\mathrm{gB}$ and $\mathrm{gH}$ was detected in $33(48.5 \%)$ patients and 29 (42.6\%) patients, respectively. A strong correlation of $\mathrm{gB}$ and $\mathrm{gH}$ was also observed here $(\mathrm{p}=0.000)$.

Table 2. The relationship between HCMV infection and clinicopathological factors.

\begin{tabular}{|c|c|c|c|c|c|c|c|c|c|c|c|c|c|}
\hline \multirow{2}{*}{ Factors } & & \multicolumn{2}{|c|}{ gB } & \multirow{2}{*}{ p-value } & \multicolumn{2}{|c|}{ gH } & \multirow{2}{*}{ p-value } & \multicolumn{2}{|c|}{ Diagnosis $1^{\star}$} & \multirow{2}{*}{ p-value } & \multicolumn{2}{|c|}{ Diagnosis $2^{*}$} & \multirow{2}{*}{ p-value } \\
\hline & & + & - & & + & - & & + & - & & + & - & \\
\hline \multirow{2}{*}{ age } & $\leq 55$ & 22 & 25 & \multirow{2}{*}{0.671} & 20 & 27 & \multirow{2}{*}{0.981} & 16 & 31 & \multirow{2}{*}{0.399} & 26 & 21 & \multirow{2}{*}{0.210} \\
\hline & $>55$ & 11 & 10 & & 9 & 12 & & 5 & 16 & & 15 & 6 & \\
\hline \multirow{2}{*}{ gender } & female & 16 & 17 & \multirow{2}{*}{0.994} & 13 & 20 & \multirow{2}{*}{0.598} & 10 & 23 & \multirow{2}{*}{0.920} & 19 & 14 & \multirow{2}{*}{0.656} \\
\hline & male & 17 & 18 & & 16 & 19 & & 11 & 24 & & 22 & 13 & \\
\hline \multirow{2}{*}{ KPS } & $\geq 70$ & 26 & 29 & \multirow{2}{*}{0.670} & 24 & 31 & \multirow{2}{*}{0.734} & 18 & 37 & \multirow{2}{*}{0.731} & 32 & 23 & \multirow{2}{*}{0.464} \\
\hline & $<70$ & 7 & 6 & & 5 & 8 & & 3 & 10 & & 9 & 4 & \\
\hline \multirow{2}{*}{$\begin{array}{l}\mathrm{IDH} \\
\mathrm{R} 132 \mathrm{H}\end{array}$} & mutant & 4 & 9 & \multirow{2}{*}{0.154} & 3 & 10 & \multirow{2}{*}{0.113} & 1 & 12 & \multirow{2}{*}{0.093} & 6 & 7 & \multirow{2}{*}{0.247} \\
\hline & wild-type & 29 & 26 & & 26 & 29 & & 20 & 35 & & 35 & 20 & \\
\hline \multirow{2}{*}{ PTEN } & absence & 5 & 6 & \multirow{2}{*}{0.824} & 3 & 8 & \multirow{2}{*}{0.428} & 2 & 9 & \multirow{2}{*}{0.523} & 6 & 5 & \multirow{2}{*}{0.929} \\
\hline & presence & 28 & 29 & & 26 & 31 & & 19 & 38 & & 35 & 22 & \\
\hline
\end{tabular}

*The patients detected with both gB and gH were grouped as "Diagnosis 1". Patients who showed either gB or gH were grouped as "Diagnosis 2". 

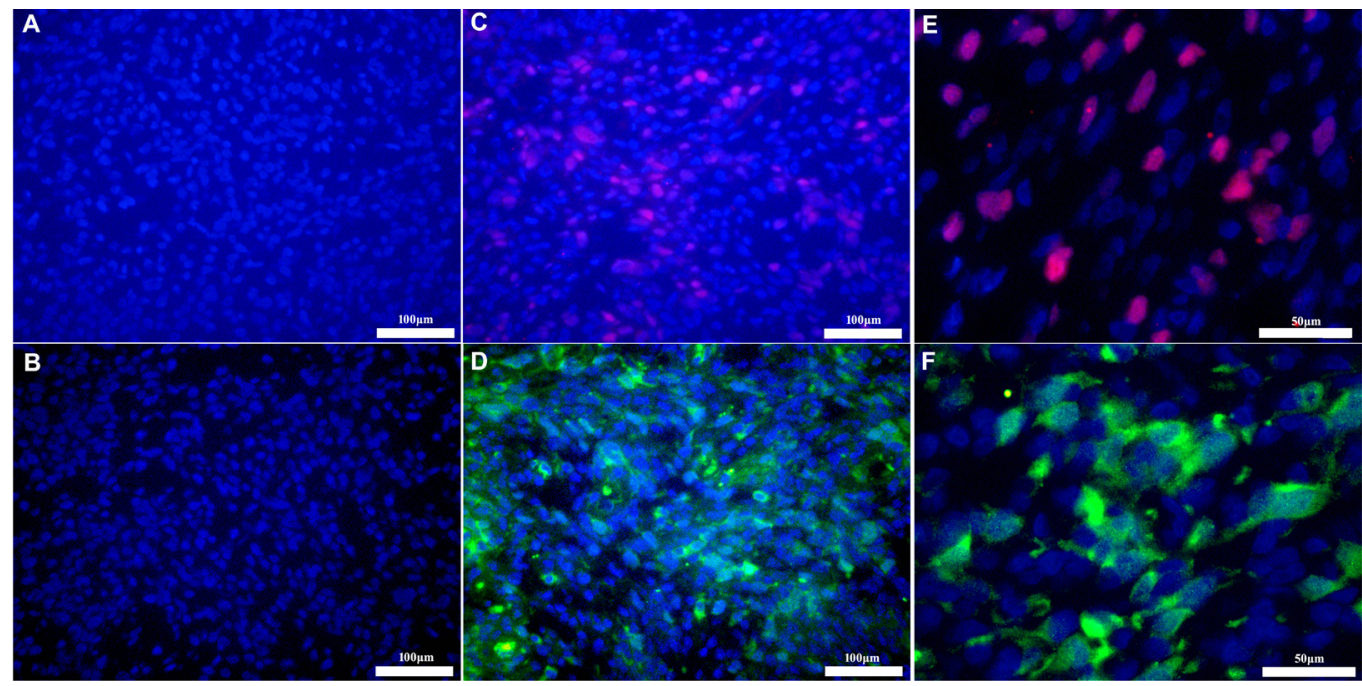

Figure 1. Immunofluorescence of $\mathrm{gB}$ and $\mathrm{gH}$. Negative $\mathrm{gB}(\mathrm{A})$ and $\mathrm{gH}(\mathrm{B})$; positive $\mathrm{gB}(\mathrm{C})$ and $\mathrm{gH}(\mathrm{D})$; enlarged view of positive $\mathrm{gB}(\mathrm{E})$ and $\mathrm{gH}(\mathrm{F})$.
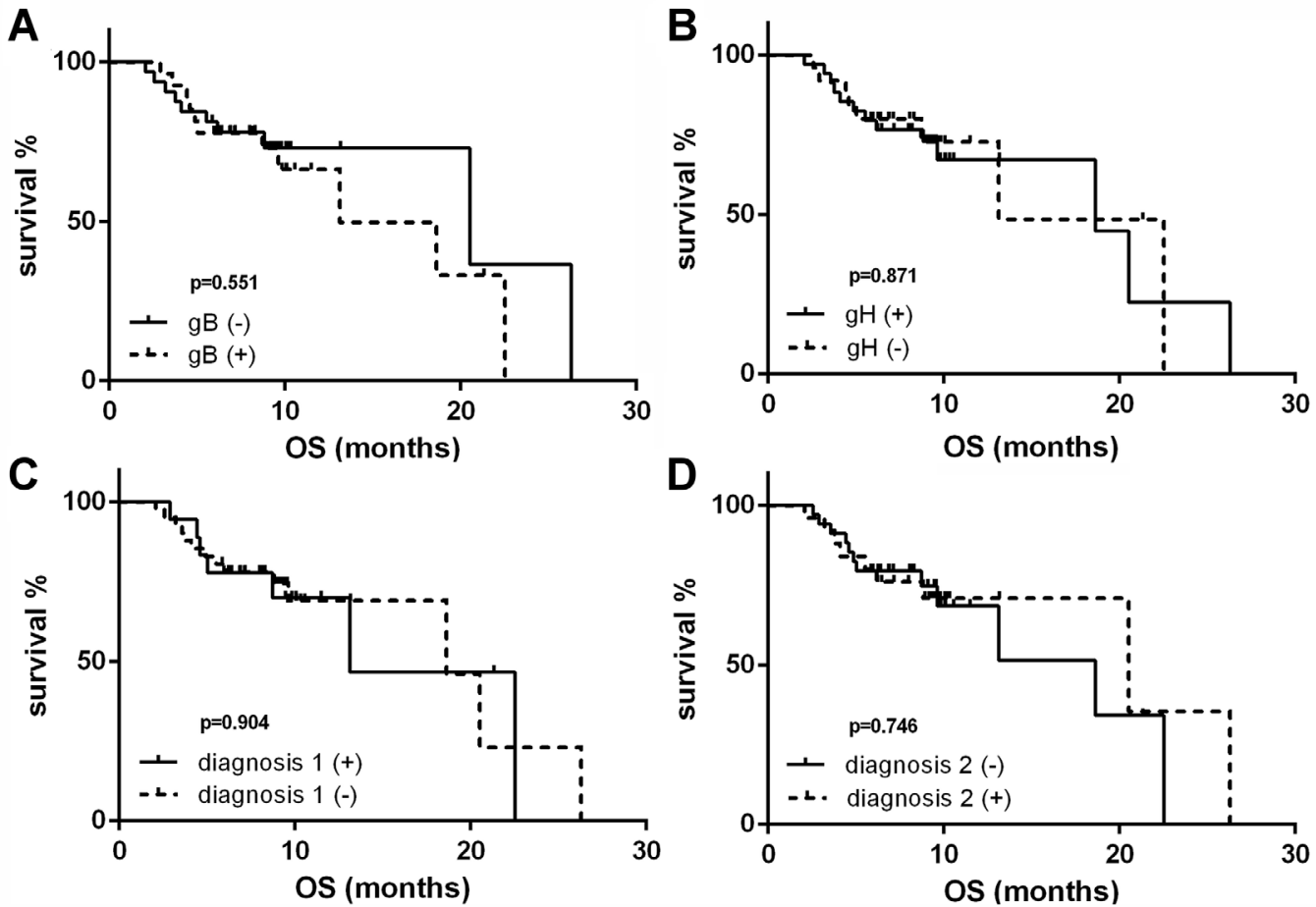

Figure 2. Kaplan-Meier survival curves according to the division of $\mathrm{gB}$ and $\mathrm{gH}$. The clinical outcomes did not differ among the groups. The overall survival in GBM patients was not related to $\mathrm{gB}(\mathrm{A})$ or $\mathrm{gH}(\mathrm{B})$, Diagnosis 1 (C) or Diagnosis 2 (D).

To improve the specificity of detecting HCMV, we classified patients detected with both $\mathrm{gB}$ and $\mathrm{gH}$ as "Diagnosis 1". Patients who showed either $\mathrm{gB}$ or $\mathrm{gH}$ were grouped as "Diagnosis 2" for the sensitivity. However, we did not find any correlations between HCMV infection and patients' clinicopathological factors (Table 2).
Survival analysis. IDH- ${ }^{\mathrm{R} 132 \mathrm{H}}$ mutations were significantly associated with longer OS [median 22.533 months (95\% CI not available) vs. 13.133 months (95\% CI 4.65321.614); $\mathrm{p}=0.006, \log$ rank test]. However, we did not find a predictive role neither of $\mathrm{gB}(\mathrm{p}=0.551, \log$ rank test, Figure $2 \mathrm{~A}$ ) nor of $\mathrm{gH}(\mathrm{p}=0.871, \log$ rank test, Figure $2 \mathrm{~B})$. 
Then, we examined the predictive role of "Diagnosis 1" and "Diagnosis 2" in glioblastomas. No correlations of OS were found neither in "Diagnosis 1" $(\mathrm{p}=0.904, \log$ rank test, Figure 2C) nor "Diagnosis 2" ( $\mathrm{p}=0.746, \log$ rank test, Figure 2D). We also detected that HCMV could predict the outcome in IDH-1 wt glioblastomas. There were no associations between the presence of HCMV and clinical outcome (data not shown).

\section{Discussion}

Herein, our study proved the infection of HCMV in glioblastoma tissues with the method of IF. However, there were many arguments addressing HCMV presence in tumor tissue and blood detected by various methods including PCR/FISH/IHC [18]. In Lau Et Al's study, no HCMV gB was found in GBM, AA, A or OA.[29] The same results were also observed in 77 brain tumors, including II-IV gliomas [28]. A study from Japan also found that HCMV gB was not present in 40 glioblastomas [9]. On the contrary, the positive rates of HCMV gB were reported to be $40.9 \%$ for grade II, $53.8 \%$ for grade III, and $61.7 \% \sim 63.1 \%$ for grade IV $[7,27]$. Our research showed that $48.5 \%(33 / 68)$ and $42.6 \%(29 / 68)$ of the patients were found positive for HCMV $\mathrm{gB}$ or $\mathrm{gH}$, respectively. The co-occurrence of $\mathrm{gB}$ and $\mathrm{gH}$ was found in 21 patients $(30.8 \%)$. The presence of either $\mathrm{gB}$ or $\mathrm{gH}$ was detected in 41 patients (60.3\%). However, no relationship was found between HCMV presence and glioma's characteristics, neither with patients' age, gender, KPS, IDH- ${ }^{\mathrm{R} 132 \mathrm{H}}$ mutations nor PTEN loss. Consequently, our results supported the fact that HCMV was present in glioblastomas. The mechanism was likely to be angiogenesis, immunosuppression, promotion of cell proliferation, tumor invasion, and inhibition of apoptosis and autophagy [32].

Additionally, the presence of HCMV was not likely to be correlated with clinical outcome in our study, which was consistent with the previous data [27]. In Ding Et Al's study, IHC was used to detect HCMV proteins IE1-72 and pp65, and PCR was adopted to measure HCMV DNA both in tumor and blood. However, none of these glioblastoma components were associated with clinical outcomes [27]. However, low GBM-infection was associated with better clinical outcomes according to several reports [33, 34]. The reasons for the inconsistent results are not clear now. However, Valganciclovir as an added-on immunotherapy within 6-months post operationally showed beneficial effect in killing tumor cells in glioblastomas. However, prolonged overall survival (OS) was not found due to the use of Valganciclovir $[35,36]$. On the contrary, the continuous usage of Valganciclovir exceeding 6 months seemed to improve OS in glioblastomas [36]. Consequently, targeting HCMV in treating glioblastomas was needed to be further investigated.

In conclusion, our results favor that HCMV is present in glioblastomas. However, no relationship between HCMV presence and patients' prognosis was found.
Acknowledgments: This work was supported and granted by the Basic and Clinical Cooperation Project of Capital Medical University (15JL08) in China.

\section{References}

[1] GILBERT MR, DIGNAM JJ, ARMSTRONG TS, WEFEL JS, BLUMENTHAL DT et al. A randomized trial of bevacizumab for newly diagnosed glioblastoma. N Engl J Med 2014; 370: 699-708. https://doi.org/10.1056/NEJMoa1308573

[2] SINGH SK, HAWKINS C, CLARKE ID, SQUIRE JA, BAYANI J et al. Identification of human brain tumour initiating cells. Nature 2004; 432: 396-401. https://doi.org/10.1038/nature 03128

[3] FORNARA O, BARTEK J, JR., RAHBAR A, ODEBERG J, KHAN Z et al. Cytomegalovirus infection induces a stem cell phenotype in human primary glioblastoma cells: prognostic significance and biological impact. Cell Death Differ 2016; 23: 261-269. https://doi.org/10.1038/cdd.2015.91

[4] SOROCEANU L, MATLAF L, KHAN S, AKHAVAN A, SINGER E et al. Cytomegalovirus Immediate-Early Proteins Promote Stemness Properties in Glioblastoma. Cancer Res 2015; 75: 3065-3076. https://doi.org/10.1158/0008-5472. CAN-14-3307

[5] COBBS CS, HARKINS L, SAMANTA M, GILLESPIE GY, BHARARA $S$ et al. Human cytomegalovirus infection and expression in human malignant glioma. Cancer Res 2002; 62: 3347-3350.

[6] LEHRER S, GREEN S, ROSENZWEIG KE, RENDO A. No circulating human cytomegalovirus in 14 cases of glioblastoma. Neuro Oncol 2015; 17: 320. https://doi.org/10.1093/ neuonc/nou325

[7] MITCHELL DA, XIE W, SCHMITTLING R, LEARN C, FRIEDMAN A et al. Sensitive detection of human cytomegalovirus in tumors and peripheral blood of patients diagnosed with glioblastoma. Neuro Oncol 2008; 10: 10-18. https://doi. org/10.1215/15228517-2007-035

[8] PRIEL E, WOHL A, TEPERBERG M, NASS D, COHEN ZR. Human cytomegalovirus viral load in tumor and peripheral blood samples of patients with malignant gliomas. J Clin Neurosci 2015; 22: 326-330. https://doi.org/10.1016/j. jocn.2014.06.099

[9] YAMASHITA Y, ITO Y, ISOMURA H, TAKEMURA N, OKAMOTO A et al. Lack of presence of the human cytomegalovirus in human glioblastoma. Mod Pathol 2014; 27: 922-929. https://doi.org/10.1038/modpathol.2013.219

[10] LAWLER SE. Cytomegalovirus and glioblastoma; controversies and opportunities. J Neurooncol 2015; 123: 465-471. https://doi.org/10.1007/s11060-015-1734-0

[11] WAKEFIELD A, PIGNATA A, GHAZI A, ASHOORI A, HEGDE $M$ et al. Is CMV a target in pediatric glioblastoma? Expression of CMV proteins, pp65 and IE1-72 and CMV nucleic acids in a cohort of pediatric glioblastoma patients. J Neurooncol 2015; 125: 307-315. https://doi.org/10.1007/ s11060-015-1905-Z 
[12] TAHA MS, ABDALHAMID BA, EL-BADAWY SA, SOROUR YM, ALMSNED FM et al. Expression of cytomegalovirus in glioblastoma multiforme: Myth or reality? Br J Neurosurg 2016; 307-312. https://doi.org/10.3109/02688697.201 5.1119241

[13] DEY M, AHMED AU, LESNIAK MS. Cytomegalovirus and glioma: putting the cart before the horse. J Neurol Neurosurg Psychiatry 2015; 86: 191-199. https://doi.org/10.1136/jnnp2014-307727

[14] BAUMGARTEN P, MICHAELIS M, ROTHWEILER F, STARZETZ T, RABENAU HF et al. Human cytomegalovirus infection in tumor cells of the nervous system is not detectable with standardized pathologico-virological diagnostics. Neuro Oncol 2014; 16: 1469-1477. https://doi.org/10.1093/ neuonc/nou 167

[15] SOLOMON IH, RAMKISSOON SH, MILNER DA, JR., FOLKERTH RD. Cytomegalovirus and glioblastoma: a review of evidence for their association and indications for testing and treatment. J Neuropathol Exp Neurol 2014; 73: 994-998. https://doi.org/10.1097/NEN.0000000000000125

[16] LIBARD S, POPOVA SN, AMINI RM, KARJA V, PIETILAINEN $T$ et al. Human cytomegalovirus tegument protein pp65 is detected in all intra- and extra-axial brain tumours independent of the tumour type or grade. PLoS One 2014; 9: e108861. https://doi.org/10.1371/journal.pone.0108861

[17] DE PASCHALE M, AGRAPPI C, MANCO MT, CLERICI P. Positive predictive value of anti-HCMV IgM as an index of primary infection. J Virol Methods 2010; 168: 121-125. https://doi.org/10.1016/j.jviromet.2010.05.001

[18] SCHEURER ME, BONDY ML, ALDAPE KD, ALBRECHT T, EL-ZEIN R. Detection of human cytomegalovirus in different histological types of gliomas. Acta Neuropathol 2008; 116: 79-86. https://doi.org/10.1007/s00401-008-0359-1

[19] HUANG R, QIAN D, HU M, ZHANG X, SONG J et al. Association between human cytomegalovirus infection and histone acetylation level in various histological types of glioma. Oncol Lett 2015; 10: 2812-2820. https://doi.org/10.3892/ ol.2015.3638

[20] PARSONS DW, JONES S, ZHANG X, LIN JC, LEARY RJ et al. An integrated genomic analysis of human glioblastoma multiforme. Science 2008; 321: 1807-1812. https://doi. org/10.1126/science. 1164382

[21] HARTMANN C, MEYER J, BALSS J, CAPPER D, MUELLER $\mathrm{W}$ et al. Type and frequency of IDH1 and IDH2 mutations are related to astrocytic and oligodendroglial differentiation and age: a study of 1,010 diffuse gliomas. Acta Neuropathol 2009; 118: 469-474. https://doi.org/10.1007/ s00401-009-0561-9

[22] WANG PF, LIU N, SONG HW, YAO K, JIANG T et al. IDH1R132Hmutation status in diffuse glioma patients: implications for classification. Oncotarget 2016; 7: 31393-31400.

[23] REUSS DE, MAMATJAN Y, SCHRIMPF D, CAPPER D, HOVESTADT $\mathrm{V}$ et al. IDH mutant diffuse and anaplastic astrocytomas have similar age at presentation and little difference in survival: a grading problem for WHO. Acta Neuropathol 2015; 129: 867-873. https://doi.org/10.1007/ s00401-015-1438-8
[24] CACHIA D, KAMIYA-MATSUOKA C, MANDEL JJ, OLAR A, CYKOWSKI MD et al. Primary and secondary gliosarcomas: clinical, molecular and survival characteristics. J Neurooncol 2015; 125: 401-410. https://doi.org/10.1007/s11060015-1930-y

[25] LOUIS DN, PERRY A, REIFENBERGER G, VON DEIMLING A, FIGARELLA-BRANGER D et al. The 2016 World Health Organization Classification of Tumors of the Central Nervous System: a summary. Acta Neuropathol 2016; 131: 803-820. https://doi.org/10.1007/s00401-016-1545-1

[26] EISENBERG RJ, ATANASIU D, CAIRNS TM, GALLAGHER JR, KRUMMENACHER C et al. Herpes Virus Fusion and Entry: A Story with Many Characters. Viruses 2012; 4: 800-832. https://doi.org/10.3390/v4050800

[27] DING D, HAN S, WANG Z, GUO Z, WU A. Does the existence of $\mathrm{HCMV}$ components predict poor prognosis in glioma? J Neurooncol 2014; 116: 515-522. https://doi. org/10.1007/s11060-013-1350-9

[28] POLTERMANN S, SCHLEHOFER B, STEINDORF K, SCHNITZLER P, GELETNEKY K et al. Lack of association of herpesviruses with brain tumors. J Neurovirol 2006; 12: 90-99. https://doi.org/10.1080/13550280600654573

[29] LAU SK, CHEN YY, CHEN WG, DIAMOND DJ, MAMELAK AN et al. Lack of association of cytomegalovirus with human brain tumors. Mod Pathol 2005; 18: 838-843. https:// doi.org/10.1038/modpathol.3800352

[30] WANG PF, LI HL, QI X, YAO K, HAN S et al. Clinical significance of angiopoietin-like protein 3 expression in patients with glioblastoma. Neoplasma 2015; 63: 93-98. https://doi. org/10.4149/neo_2016_011

[31] STUPP R, MASON WP, VAN DEN BENT MJ, WELLER M, FISHER B et al. Radiotherapy plus concomitant and adjuvant temozolomide for glioblastoma. N Engl J Med 2005; 352: 987-996. https://doi.org/10.1056/NEJMoa043330

[32] JOSEPH GP, MCDERMOTT R, BARYSHNIKOVA MA, COBBS CS, ULASOV IV. Cytomegalovirus as an oncomodulatory agent in the progression of glioma. Cancer Lett 2016; 384: 79-85. https://doi.org/10.1016/j.canlet.2016.10.022

[33] RAHBAR A, STRAGLIOTTO G, ORREGO A, PEREDO I, TAHER C et al. Low levels of Human Cytomegalovirus Infection in Glioblastoma multiforme associates with patient survival; -a case-control study. Herpesviridae 2012; 3: 3. https://doi.org/10.1186/2042-4280-3-3

[34] RAHBAR A, ORREGO A, PEREDO I, DZABIC M, WOLMER-SOLBERG $\mathrm{N}$ et al. Human cytomegalovirus infection levels in glioblastoma multiforme are of prognostic value for survival. J Clin Virol 2013; 57: 36-42. https://doi. org/10.1016/j.jcv.2012.12.018

[35] PRINS RM, CLOUGHESY TF, LIAU LM. Cytomegalovirus immunity after vaccination with autologous glioblastoma lysate. N Engl J Med 2008; 359: 539-541. https://doi. org/10.1056/NEJMc0804818

[36] STRAGLIOTTO G, RAHBAR A, SOLBERG NW, LILJA A, TAHER $C$ et al. Effects of valganciclovir as an add-on therapy in patients with cytomegalovirus-positive glioblastoma: a randomized, double-blind, hypothesis-generating study. Int J Cancer 2013; 133: 1204-1213. https://doi.org/10.1002/ ijc. 28111 